\title{
Correlation between the weather in 2017 and the productivity of maize
}

\author{
Péter Kovács - Mihály Sárvári \\ University of Debrecen, Faculty of Agriculture, Food Sciences and Environmental Management, \\ Institute of Plant Sciences, Debrecen \\ kovacs.peter@agr.unideb.hu
}

\begin{abstract}
SUMMARY
In our research we examined the effect of the hybrid, the nutrient supply, the number of plants and the abiotic factors (temperature, amount of precipitation) on the yield, crop quality and yield stability of maize. We devoted special attention to the natural nutrient utilization ability and fertilizer reaction of maize. The experiment took place in Hajdúszoboszló on chernozem soil, on a nearly 8 ha field. The size of one plot was $206 \mathrm{~m}^{2}$; therefore, this experiment was half-industrial. We tested six hybrids with different genetic characteristics and growing seasons. I analysed the correlation between the nutrient supply and the yield of maize hybrids with control treatment (treatment without fertilization) and with $\mathrm{N} 80, \mathrm{P}_{2} \mathrm{O}_{5} 60, \mathrm{~K}_{2} \mathrm{O} 70 \mathrm{~kg} \mathrm{ha}^{-1}$ and $\mathrm{N} \mathrm{160,} \mathrm{P}_{2} \mathrm{O}_{5} 120, \mathrm{~K}_{2} \mathrm{O} 140 \mathrm{~kg} \mathrm{ha}^{-1}$ fertilizer treatments. The yield increasing effect of the fertilizer also depended on the number of plants per hectare to a great extent. The number of plants of the six tested hybrids was 60 , 70, and 80 thousand plants $h a^{-1}$.

In Hajdúszoboszló in 2017, up to October, $445.8 \mathrm{~mm}$ of rain fell, which is in line with the average values of 30 years, and is only $45.7 \mathrm{~mm}$ less than those. In 2017, the effect of increasing the plant number was slighter. Averaged over the observed fertilizer treatments and hybrids,

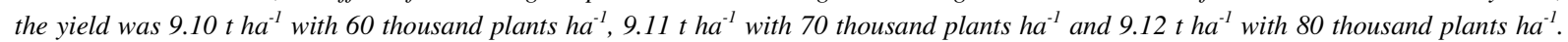
Without fertilization, in most cases, increasing the plant number from 60 thousand plants ha-1 to 70-80 thousand plants ha ${ }^{-1}$ does not increased the yield but decreased it. With $N_{80}+P K$ treatment the yield changed between 8.90 and 11.27 tha ${ }^{-1}$. The effect of increasing the plant number was just slightly observable and did not show a clear tendency. The effect of changing the plant number, even with the highest dosage of fertilizers, could not be detected adequately. In contrast with the plant number, the effect of the different fertilizer treatments was expressly traceable. Compared to the control treatment (treatment without fertilization), with $N_{80}+P K$ fertilizer dosage with 60 thousand plants $h a^{-1}$ the yield increased by 3.36-4.99 $t \mathrm{ha}^{-1}$. The smallest demonstrable proof, i.e. the LSD S $_{5}$ ws $0.22 t$ ha ${ }^{-1}$, which means that fertilization, in each case, significantly increased the yield. When analysing the effect of fertilization in the average of the hybrids and the

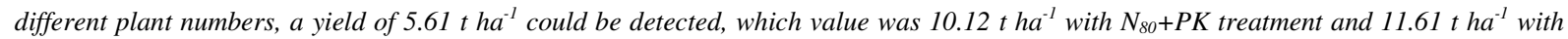
$N_{160}+P K$ treatment. Thus, it can be calculated that compared to the treatment without fertilization, the $N_{80}+P K$ treatment increased the yield

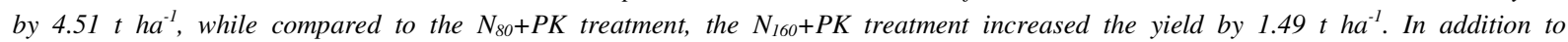
agrotechnical factors, in maize production, the impact of the crop year is specifically of high importance.

The average yield of hybrids (in the average of the different fertilizer treatments) was $6.81 \mathrm{tha} \mathrm{a}^{-1}$ in $2015,11.86 \mathrm{tha}$ in 2016 and $9.11 \mathrm{t}$ ha ${ }^{-1}$ in 2017. When comparing the yield results against the precipitation data, it is clearly visible that the amount of rain fell in the JanuaryOctober period is directly proportional to the average yield of maize. The effect of the crop year can be defined in a 5.05 t ha ${ }^{-1}$ difference in the yield.
\end{abstract}

Keywords: maize, nutrient supply, number of plants, year effect, hybrid

\section{INTRODUCTION}

According to Sárvári et al. (2008) there are a number of agricultural techniques that can counteract the droughty crop years generated by the progressional climatic change. Among those, the appropriate crop rotation, a moderate number of plants $\mathrm{ha}^{-1}$ and the application of hybrids with good adaptability, suitable for the given ecological characteristics have an outstanding significance. According to Nagy and Sárvári (2005), due to the extreme weather conditions, one of the most important criteria for hybrids is adaptability. According to Pepó's et al. (2016) longterm experiments, the basis of effective production is choosing the adaptive genotype, and the application of the agricultural techniques proper for the place of production and the needs of the hybrid. Besides its influence on the yield, the crop year has an outstanding effect on the indicators of the yield, where the most important are the yield per cob, the grain weight and the length of cob (Hegyi et al. 2002). To maintain the yield stability of maize, essential conditions are choosing a hybrid adjusted to the given ecological circumstances, the balanced distribution of nutrients, choosing the optimal date of sowing, crop rotation and plant number according to the ecological, biological and agrotechnical factors (Sárvári 2005). In order to ensure the profitability of maize production a professionally planned fertilization is necessary, the effect of which will be determined by water and nutrient supply. It is important to define the appropriate fertilizer dosage, for which the nutrient utilization capability of plants, their response to fertilization and the crop year need to be taken into account (Nagy 2007). The fertilizer need can be higher or lower, than the amount of that utilized by the crop, thus, consequently, the amount of nutrient needed by the plant does not equal to the fertilizer dosage that is to be spread. In addition, the nutrient requirements of the varieties can also be different (Menyhért 1985). It can be concluded that in crop years with inadequate amount of precipitation numbers of plants ha ${ }^{-1}$ over 60-70 thousand caused $7-14 \%$ decrease in the yield (Nagy and Megyes 2009). The analyses have shown 
that in a place of production with favourable characteristics and agronomical factors, the efficiency of maize production can be improved only by applying a stand density that is specific to the hybrid (Pepó et al. 2002). Nagy (2008) have found that with a plant number higher than 70 thousand plants $\mathrm{ha}^{-1}$, the stand becomes extremely sensitive to droughty periods. It is essential to determine the interval of the optimum plant number with which the yield does not increase significantly. At the time of sowing, it cannot be predicted what the crop year will be like, therefore, with every hybrid, the minimum or medium value of that optimum plant number interval is expedient to be applied. The difference between the optimum plant numbers in a droughty crop year and in one with more precipitation can even be 15-20 thousand plants $\mathrm{ha}^{-1}$ with the same hybrid (Sárvári et al. 2007).

\section{MATERIAL AND METHOD}

The experiment took place in Hajdúszoboszló on chernozem soil, on a nearly 8 ha field. The size of one plot was $206 \mathrm{~m}^{2}$, thus it was a half-industrial experiment. We tested six hybrids with different genetic characteristics and growing seasons. I analysed the correlation between the nutrient supply and the yield of maize hybrids with control treatment (treatment without fertilization) and with $\mathrm{N} 80, \mathrm{P}_{2} \mathrm{O}_{5}$ $60, \mathrm{~K}_{2} \mathrm{O} 70 \mathrm{~kg} \mathrm{ha}^{-1}$ and $\mathrm{N} 160, \mathrm{P}_{2} \mathrm{O}_{5} 120, \mathrm{~K}_{2} \mathrm{O} 140 \mathrm{~kg}$ $\mathrm{ha}^{-1}$ fertilizer treatments. In our experiment, the same fertilizer dosages have been applied for the $3^{\text {rd }}$ year now (it is not a long-term experiment). The yield increasing effect of the fertilizer also depended on the number of plants per hectare at a great extent. The number of plants of the six tested hybrids was 60,70 , and 80 thousand plants $\mathrm{ha}^{-1}$. The natural capability of nutrient intake and usage and the fertilizer response of maize were expressed in numbers.

In Hajdúszoboszló in 2017, up to October, 445.8 $\mathrm{mm}$ of rain fell, which is in line with the average values of 30 years, and is only $45.7 \mathrm{~mm}$ less than those (Figure 1). Although in May there was only 28 $\mathrm{mm}$ of precipitation which is half of the usual amount, in the period most critical for maize (during flowering and fertilization) the amount of precipitation was adequate, and there was no extreme value among the monthly temperature data either. Thus, it can be considered as an absolutely average year.

Fertilizers were spread on the field in two runs: the phosphorus and potassium fertilizer dosages were spread in autumn, before ploughing, while the nitrogen was spread in spring, before sowing and was immediately incorporated in the soil. Sowing took place on 1 May 2017 with an 8-row John Deere sowing equipment. Harvesting took place on 21 October 2017. An industrial harvester and a Schrran type axle scale were applied to determine the yield results. Those results per plot were recalculated in yield per hectare and for $14 \%$ moisture content.
Figure 1: Weather conditions (Hajdúszoboszló, 2017)

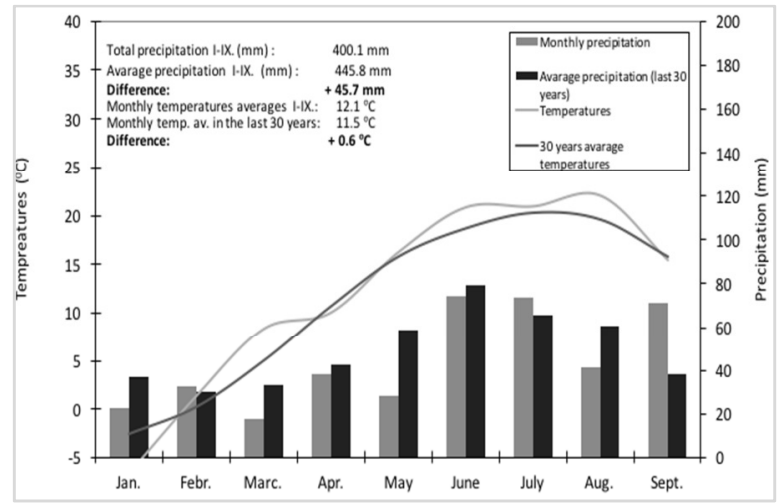

Values of the gained results were evaluated by using SPSS 22.0 statistical programme. After registering the data gained during sampling, one- and two-way analyses of variance were applied, with which the effect of the different fertilizer treatments and plant numbers and the differences between the hybrids can be revealed. According to the null hypothesis of the F-test of the variance analysis there is no statistically detectable difference between the effects of the different treatments, meaning that they have the same influence on the yield of maize. However, in case the F-test is significant, the null hypothesis is rejected, which refers to statistically detectable differences between the treatments. The significant differences between the treatments were demonstrated by the LSD test. In the F-test and the LSD-test a significance level of 0.05 was applied.

\section{RESULTS}

In 2017 , the effect of increasing the plant number was slighter (Figure 2-4). In the average of the fertilizer treatments and the hybrids, the yield was $9.10 \mathrm{t} \mathrm{ha}^{-1}$ with 60 thousand plants $\mathrm{ha}^{-1}, 9.11 \mathrm{t} \mathrm{ha}^{-1}$ with 70 thousand plants ha ${ }^{-1}$ and $9.12 \mathrm{t} \mathrm{ha}^{-1}$ with 80 thousand plants ha ${ }^{-1}$.

Without fertilization, in most cases, increasing the plant number from 60 thousand plants $\mathrm{ha}^{-1}$ to $70-80$ thousand plants ha ${ }^{-1}$ does not increased the yield but decreased it. Soils have a natural productivity, which can ensure a certain yield level. Since 2017 was the $3^{\text {rd }}$ year of our experiment, the natural nutrient content of the soils had considerably reduced. Without fertilization, the tested hybrids reached a yield of 4.98-6.28 $\mathrm{t} \mathrm{ha}^{-1}$ and within that interval a higher yield was produced with the lower plant number of 60 thousand plants $\mathrm{ha}^{-1}$. Without added nutrients, the higher number of plants of 80 thousand plants ha $^{-1}$ generated a depression in the yield (Figure 2).

With the $\mathrm{N}_{80}+\mathrm{PK}$ treatment yield results varied between 8.90 and $11.27 \mathrm{tha}^{-1}$. The effect of increasing the plant number could be slightly observed and did not show a clear tendency. The differences did not even exceed or were higher only at a minimum extent than the significance level (LSD $5 \%$ plant number: 0.20 $\mathrm{t} \mathrm{ha}^{-1}$ (Figure 3). 
The effect of increasing the plant number could not be significantly observed with the highest dosage of fertilizer either. From the six hybrids, five produced a lower yield with the 60 thousand plants ha $^{-1}$ stand density than with the higher one. However, with the 70 and 80 thousand plants $\mathrm{ha}^{-1}$ stand density the differences were not considerable. The highest yield was produced by hybrid P9486, which was $12.45 \mathrm{tha}^{-1}$ with $\mathrm{N}_{180}+\mathrm{PK}$ treatment and 60 thousand plants ha ${ }^{-1}$ stand density (Figure 4).

Figure 2: The effect of the increase of the number of plants on the yield of maize hybrids (control, Hajdúszoboszló, 2017)

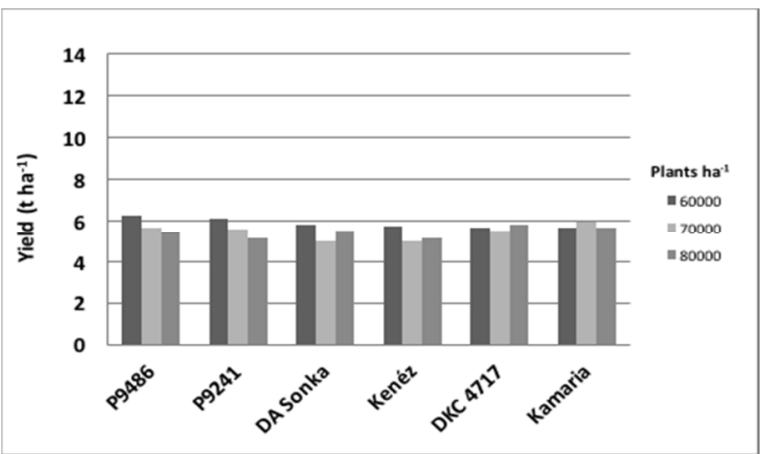

Figure 3: The effect of the increase of the number of plants on the yield of maize hybrids

( $\mathrm{N}_{80}+$ PK, Hajdúszoboszló, 2017)

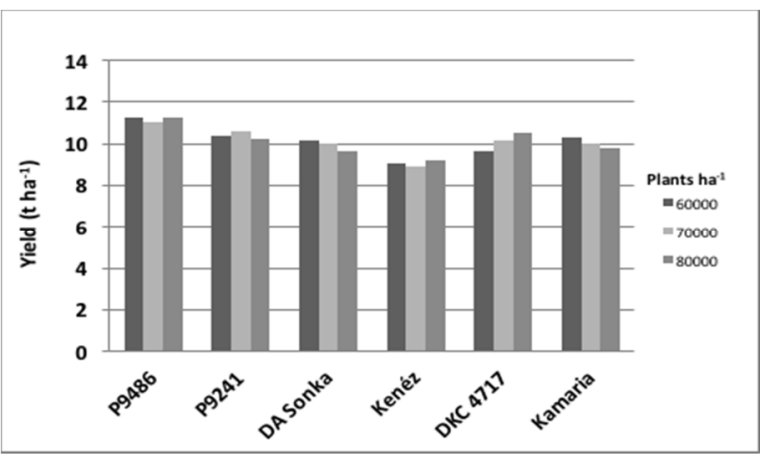

Figure 4: The effect of the increase of the number of plants on the yield of maize hybrids

( N160 $_{10 K}$, Hajdúszoboszló, 2017)

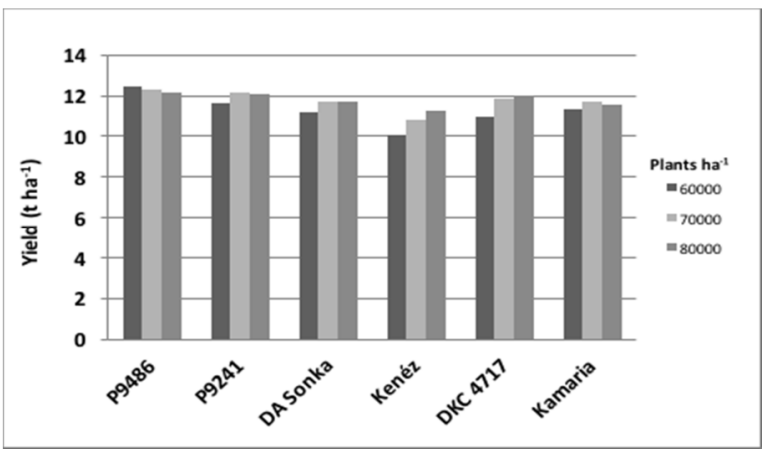

In 2017, in contrast with the effect of the plant number, that of the fertilizer treatments could be clearly detected. Compared to the control treatment (treatment without fertilization), the $\mathrm{N}_{80}+\mathrm{PK}$ treatment with 60 thousand plants $\mathrm{ha}^{-1}$ increased the yield by $3.36-4.99 \mathrm{t} \mathrm{ha}^{-1}$. The increase of $3.36 \mathrm{t} \mathrm{ha}^{-1}$ was reached with the less modern hybrid Kenéz, while it was almost $5 \mathrm{t} \mathrm{ha}^{-1}\left(4.99 \mathrm{t} \mathrm{ha}^{-1}\right)$ with the modern hybrid P9486. With a plant number of 60 thousand plants $\mathrm{ha}^{-1}$, compared to the $\mathrm{N}_{80}+\mathrm{PK}$ nutrient level, the $\mathrm{N}_{160}+\mathrm{PK}$ treatment generated a further $0.99-1.35 \mathrm{t} \mathrm{ha}^{-1}$ increase in the yield (Figure 1).

With control treatment and 70 thousand plants ha ${ }^{-1}$, the hybrids produced yield results between 4.98-5.98 t $\mathrm{ha}^{-1}$, and with $\mathrm{N}_{80}+\mathrm{PK}$ treatment the yields increased to amounts between 8.91 and $11.03 \mathrm{t} \mathrm{ha}^{-1}$. With the highest nutrient dosage these values changed between 10.79 and $12.30 \mathrm{t} \mathrm{ha}^{-1}$ (Figure 5). The yield increasing effect of fertilization was stronger than that of the control, especially with an appropriate plant number per unit area.

\section{Figure 5: The effect of NPK fertilizer treatments} on the yield of maize hybrids

(70 thousand plants ha ${ }^{-1}$, Hajdúszoboszló, 2017)

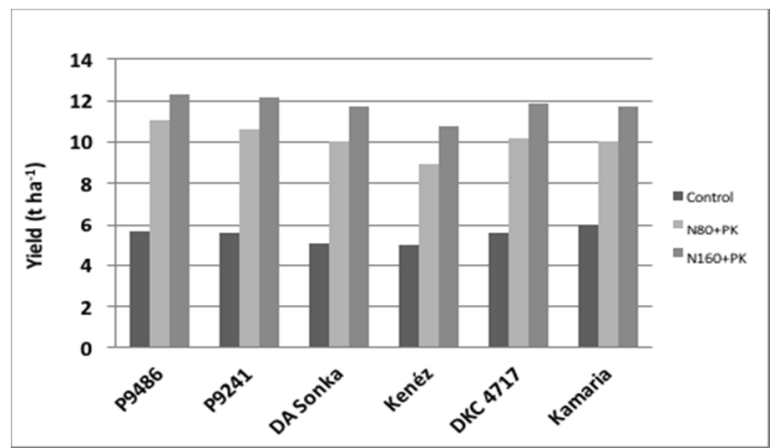

Compared to the control, with 80 thousand plants $\mathrm{ha}^{-1}$ stand density the $\mathrm{N}_{80}+\mathrm{PK}$ increased the yield by 3.77-5.39 $\mathrm{t} \mathrm{ha}^{-1}$, while compared to the $\mathrm{N}_{80}+\mathrm{PK}$ treatment, the $\mathrm{N}_{160}+\mathrm{PK}$ treatment increased the yield by $1.14-1.59 \mathrm{t} \mathrm{ha}{ }^{-1}$. The smallest demonstrable difference, i.e. the $\mathrm{LSD}_{5 \%}$, was $0.22 \mathrm{t} \mathrm{ha}^{-1}$, so fertilization significantly increased the yield in each case. Looking at the effect of fertilization in the average of the hybrids and plant numbers, we can assess that the yield was $5.61 \mathrm{t} \mathrm{ha}^{-1}$ with treatment without fertilization, it was $10.12 \mathrm{t} \mathrm{ha}^{-1}$ with $\mathrm{N}_{80}+\mathrm{PK}$ treatment, while with $\mathrm{N}_{160}+\mathrm{PK}$ treatment it was 11.61 $\mathrm{t} \mathrm{ha}^{-1}$. Thus, it can be calculated that compared to the treatment without fertilization, the $\mathrm{N}_{80}+\mathrm{PK}$ treatment increased the yield by $4.51 \mathrm{t} \mathrm{ha}^{-1}$, while compared to the $\mathrm{N}_{80}+\mathrm{PK}$ treatment, the $\mathrm{N}_{160}+\mathrm{PK}$ treatment increased it by $1.49 \mathrm{t} \mathrm{ha}^{-1}$ (Table 1 ).

In maize production, besides the agrotechnical factors, the effect of the crop year is of great importance. Comparing the year 2017 to the previous 2 years, the following can be concluded. In Hajdúszoboszló, from January to October in 2015, the amount of precipitation was $340.3 \mathrm{~mm}$, which is 105.5 $\mathrm{mm}$ less than the average of 30 years. That year was 
not only droughty, but extremely hot as well. In the crucial months of the growing season the distribution of precipitation was unfavourable for maize. In 2016 the crop year was favourable for stoop crops, thus for maize as well. The distribution of precipitation was especially advantageous. In 2016, the total amount of rain from January to October was $605 \mathrm{~mm}$ which is more by $160 \mathrm{~mm}$ than the average of 30 years. 2017 as I have already mentioned above - can be considered as an average year, when up to October, $445 \mathrm{~mm}$ of rain fell.

Table 1

Efficiency of NPK fertilization on yield of maize hybrids with different plant densities (Hajdúszoboszló, 2017)

\begin{tabular}{|c|c|c|c|c|c|}
\hline \multirow{2}{*}{ Hybrid } & \multirow{2}{*}{$\begin{array}{r}\text { Fertilizer } \\
\left(\mathrm{kg} \mathrm{h}^{-1}\right)\end{array}$} & \multicolumn{4}{|c|}{ Number of plants per ha } \\
\hline & & 60.000 & 70.000 & 80.000 & Average \\
\hline \multirow{3}{*}{ P9486 } & Control & - & - & - & - \\
\hline & $\mathrm{N}_{80}+\mathrm{PK}$ & 4.99 & 5.38 & 5.80 & 5.39 \\
\hline & $\mathrm{N}_{160}+\mathrm{PK}$ & 1.18 & 1.27 & 0.96 & 1.14 \\
\hline \multirow{3}{*}{ P9241 } & Control & - & - & - & - \\
\hline & $\mathrm{N}_{80}+\mathrm{PK}$ & 4.25 & 5.00 & 5.05 & 4.77 \\
\hline & $\mathrm{N}_{160}+\mathrm{PK}$ & 1.22 & 1.54 & 1.87 & 1.54 \\
\hline \multirow{3}{*}{ DA Sonka } & Control & - & - & - & - \\
\hline & $\mathrm{N}_{80}+\mathrm{PK}$ & 4.33 & 4.96 & 4.12 & 4.47 \\
\hline & $\mathrm{N}_{160}+\mathrm{PK}$ & 1.01 & 1.71 & 2.05 & 1.59 \\
\hline \multirow{3}{*}{ Kenéz } & Control & - & - & - & - \\
\hline & $\mathrm{N}_{80}+\mathrm{PK}$ & 3.36 & 3.93 & 4.02 & 3.77 \\
\hline & $\mathrm{N}_{160}+\mathrm{PK}$ & 0.99 & 1.88 & 2.04 & 1.64 \\
\hline \multirow{3}{*}{ DKC4717 } & Control & - & - & - & - \\
\hline & $\mathrm{N}_{80}+\mathrm{PK}$ & 3.95 & 4.63 & 4.69 & 4.42 \\
\hline & $\mathrm{N}_{160}+\mathrm{PK}$ & 1.35 & 1.71 & 1.49 & 1.52 \\
\hline \multirow{3}{*}{ Kamaria } & Control & - & - & - & - \\
\hline & $\mathrm{N}_{80}+\mathrm{PK}$ & 4.62 & 4.02 & 4.13 & 4.26 \\
\hline & $\mathrm{N}_{160}+\mathrm{PK}$ & 1.01 & 1.72 & 1.76 & 1.50 \\
\hline
\end{tabular}

In 2015 the average yield of the hybrids (in the average of the treatments) was $6.81 \mathrm{t} \mathrm{ha}^{-1}$. The yield of the hybrid with the weakest performance was $6.27 \mathrm{t}$ $\mathrm{ha}^{-1}$, while that with the best performance reached a yield of $7.47 \mathrm{t} \mathrm{ha}^{-1}$ (Figure 6). In 2016 the average yield was $11.86 \mathrm{t} \mathrm{ha}^{-1}$, and in 2017 it was $9.11 \mathrm{t} \mathrm{ha}^{-1}$. Comparing the yield results against the data of precipitation, it is clearly visible that the amount of precipitation fell between January and October is directly proportional to the average yield of maize. The effect of the crop year in our experiment can be determined as $5.05 \mathrm{t} \mathrm{ha}^{-1}$.

Figure 6: Average yields of hybrids (Hajdúszoboszló, 2015-2017)

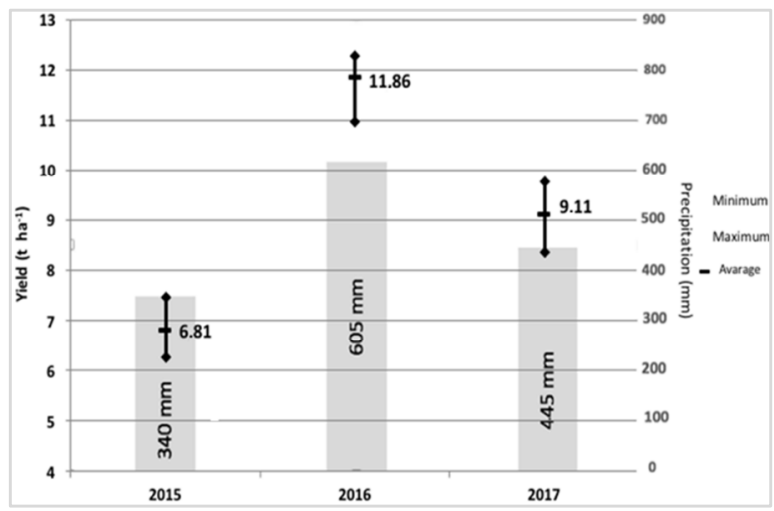

\section{DISCUSSION OF RESULTS, CONCLUSIONS}

The overall conclusion is that in a year with average precipitation, as it was 2017, the effect of the increase in the plant number is less detectable. Today's modern hybrids can excellently adapt to the low or high numbers of plants. If the stand density is too low, the individual production of plants increases.

The yield increasing effect of fertilization could be clearly observed in our experiment. With control treatment (treatment without fertilization) hybrid P9486 produced the highest yield. It proves that the natural nutrient utilization capability of the hybrid is outstanding, which a genetically heritable characteristic. Also, its response to fertilization was the best, as compared to the control treatment, with the $\mathrm{N}_{80}+\mathrm{PK}$ treatment its yield increased by $5.39 \mathrm{t} \mathrm{ha}^{-1}$. This hybrid has revealed its excellent capability of nutrient utilization.

The effect of the crop year resulted in more than 5 $\mathrm{t} \mathrm{ha}^{-1}$, which can be considered as significant. One of the most important objectives of modern maize production would be the reduction of high differences between the yields results of the different crop years, which is a fundamental condition for the improvement of yield stability.

\section{REFERENCES}

Hegyi Zs.-Pók I.-Illés O.-Szőke Cs.-Kizmus L.-Marton L. Cs. (2002): A termőhely, a tőszám és az évjárat hatása a kukorica hibridek terméselemeire. Növénytermelés. 51. 4: 425-435.

Menyhért Z. (1985): A kukoricatermesztés kézikönyve. Mezőgazdasági Kiadó. Budapest. 559.

Nagy J.-Megyes A. (2009): A kukoricatermesztés kritikus agrotechnikai elemei. Agrofórum Extra. 20. 32: 36-40.

Nagy J.-Sárvári M. (2005): Kukorica. [In: Antal J. (szerk.) A növénytermesztés alapjai. Első kötet. Gabonafélék.] Mezőgazda Kiadó. Budapest. 301-327.
Nagy J. (2007): Kukoricatermesztés. Akadémiai Kiadó. Budapest. 23-25., 222-240.

Nagy J. (2008): Az intenzív kukoricatermesztés meghatározó tényezői. Agrofórum. 19. 4: 26-29.

Pepó P.-Sárvári M.-Tótin Á.-Vad A. (2016): Kukoricatermesztés korszerüen. Magyar Mezőgazdaság. 71. 13: 24-26.

Pepó P.-Szabó A.-Sziebert D. (2002): Az állománysűrüség szerepe a fajtaspecifikus kukoricatermesztésben. Agrofórum. 13: 3: 3436. 
Sárvári M.-El Hallof N.-Molnár Zs. (2007): A tőszám hatása a kukoricahibridek termésére. Agrofórum Extra. 18. 17: 7-9.

Sárvári M.-El Hallof N.-Molnár Zs. (2008): A klimatikus tényezők és változásuk hatása a kukoricatermesztés biztonságára. Agrofórum Extra. 22. 1: 8-12.
Sárvári, M. (2005): Impact of nutrient supply, sowing time and plant density on maize yields. Acta Agronomia Hungarica. 53. 1: 59-70. 